\title{
Extension of the known distribution range and habitat use of the Tiger Crab Aegla concepcionensis Schmitt, 1942 (Decapoda, Aeglidae)
}

\author{
Francisco Correa-Araneda ${ }^{1, \delta}$ iD, Ximena Jaque-Jaramillo ${ }^{1,10}$, Carlos Esse ${ }^{1}$ iD, Pablo Saave- \\ dra1,11 (iD), Alfredo Ulloa-Yáñez 1,2,12 iD, Juan Martin 1,2, Patricio De los Ríos-Escalante ${ }^{2,3}$ iD, \\ Luz Boyero ${ }^{4,5}$ iD, Katalina Ovalle ${ }^{6}$, Rodrigo Santander-Massa ${ }^{1,7}$ iD and Guillermo Figueroa- \\ Muñoz $2,8,9, \delta,{ }^{*}$ iD
}

${ }^{1}$ Unidad de Cambio Climático y Medio Ambiente (UCCMA), Instituto Iberoamericano de Desarrollo Sostenible (IIDS), Facultad de Arquitectura, Construcción y Medio Ambiente, Universidad Autónoma de Chile, Temuco, Chile.

2 Facultad de Recursos Naturales, Universidad Católica de Temuco, Casilla 15-D, Temuco, Chile.

3 Núcleo de Estudios Ambientales, UC Temuco.

4 Department of Plant Biology and Ecology, University of the Basque Country, Leioa, Spain.

5 Ikerbasque, Bilbao, Spain.

6 AquaExpert, Santiago, Chile.

7 Programa de Doctorado en Ecosistemas Forestales y Recursos Naturales, Facultad de Ciencias Forestales y Recursos Naturales, Universidad Austral de Chile.

8 Genomic in Ecology, Evolution and Conservation Laboratory (GEECLAB), Departamento de Zoología, Facultad de Ciencias Naturales y Oceanográficas, Universidad de Concepción, Concepción, Chile.

9 Programa de Magíster en Ciencias mención en Pesquerías, Facultad de Ciencias Naturales y Oceanográficas, Universidad de Concepción, Casilla 160-C, Concepción, Chile.

10 Escuela de Graduados de la Facultad de Filosofía y Humanidades, Programa de Magíster en Comunicación, Universidad Austral de Chile, Chile.

11 Escuela de Graduados, Facultad de Ciencias Agrarias, Universidad Austral de Chile.

12 Programa de Magíster en Ciencias Biológicas, Facultad de Ciencias. Universidad de Chile, Chile.

$\delta$ These authors equally contributed to the manuscript

* Corresponding author: guillefigueroa@udec.cl

Received: 29/10/20

Accepted: 22/09/21

\begin{abstract}
Extension of the known distribution range and habitat use of the Tiger Crab Aegla concepcionensis Schmitt, 1942 (Decapoda, Aeglidae)

The tiger crab Aegla concepcionensis Schmitt, 1942 (Decapoda, Aeglidae) is a threatened freshwater decapod, endemic of Chile, with significant gaps in knowledge about its biology and ecology. The aim of this work was to contribute to the knowledge of the ecology of $A$. concepcionensis, through the extension of its known distribution range, recorded in a new type of ecosystem, and the description of the physicochemistry, vegetation and benthic macroinvertebrate and microalgal communities of those sites, which provides information about habitat use of the species. Our results show the presence of $A$. concepcionensis until $270 \mathrm{~km}$ south of the previously described range and reveal that the species inhabits streams and lakes. A. concepcionensis is associated to environments with cold and temperate waters, well oxygenated, with neutral $\mathrm{pH}$ and low conductivity, and characterized by low anthropic intervention, which is reflected in the high proportion of native riverine plant species and the high diversity of macroinvertebrate and microalgal benthic communities. We conclude that the previously restricted known distribution range of this species was mainly due to low sampling effort or misidentifications. Our results indicate that anthropic intervention should be avoided or minimized in the distribution area of $A$. concepcionensis, especially in those areas associated with urban expansion and touristic activities in streams and lakes.
\end{abstract}


Key words: Aegla concepcionensis, distribution, habitat, freshwater, Chile

\begin{abstract}
RESUMEN
Extensión del rango de distribución conocido y uso de hábitat del cangrejo tigre Aegla concepcionensis Schmitt, 1942 (Decapoda, Aeglidae)

El cangrejo tigre Aegla concepcionensis Schmitt, 1942 (Decapoda, Aeglidae) es un decápodo de agua dulce amenazado, endémico de Chile, con importantes brechas en el conocimiento de su biología y ecología. El objetivo de este trabajo fue contribuir al conocimiento de la ecología de A. concepcionensis, a través de la extensión del conocimiento de su distribución geográfica, registrado en un nuevo tipo de ecosistema, y la descripción fisicoquímica, vegetal y de las comunidades de macroinvertebrados bentónicos y microalgas bentónicas de esos sitios, lo cual brinda información acerca de nuevos usos de hábitat de la especie. Nuestros resultados muestran la presencia de A. concepcionensis hasta $270 \mathrm{~km}$ al sur del rango previamente descrito y que la especie habita en arroyos y lagos. Se asoció a ambientes con aguas frías y templadas, bien oxigenadas, con pH neutro y baja conductividad, que se caracterizaron por presentar baja intervención antrópica, reflejada en la alta proporción de especies vegetales nativas ribereñas y la alta diversidad de las comunidades bentónicas de macroinvertebrados y microalgas. Concluimos que su previamente restringido rango de distribución conocido se debía principalmente al bajo esfuerzo de muestreo o a identificaciones taxonómicas erróneas. Nuestros resultados indican que se debe evitar o minimizar la intervención antrópica en el área de distribución de A. concepcionensis, especialmente en aquellas áreas asociadas con la expansión urbana y actividades turísticas en arroyos y lagos.
\end{abstract}

Palabras clave: Aegla concepcionensis, distribución, hábitat, agua dulce, Chile

This is an open-access article distributed under the terms of the Creative Commons Attribution-NonCommercial 4.0 International (CC BY-NC 4.0) License.

\section{INTRODUCTION}

Aegla concepcionensis Schmitt, 1942, commonly referred to as Tiger crab or Pancora, is a freshwater decapod endemic of Chile, which belongs to the Aeglidae family. This family is composed of 83 species and subspecies, of which 20 (18 species and 2 subspecies) are present in Chile, all included in the genus $\mathrm{Ae}$ gla Leach, 1820. The genus Aegla has been described as endemic to the neotropical region in South America, which is distributed between latitudes $20^{\circ} 18^{\prime} \mathrm{S}$ in Brazil and $50^{\circ} 34^{\prime} \mathrm{S}$ in Chile (Santos \& De Siqueria Bueno, 2020) and it is the only taxon of the Anomura infraorder that is restricted to fresh waters (Schmitt, 1942; Bond-Buckup et al., 2008; Jara, 2013; Santos et al., 2017). According to fossil evidence (Feldmann, 1986; Feldmann et al., 1998), the origin of freshwater aeglids is marine. Invasion of fresh waters occurred due to marine transgressions that occurred during the early formation of the Andean Mountain range in the Late Cretaceous-Early Tertiary, around 90 to 60 million years ago (Pérez-Losada et al., 2004), with dis- persion in the region between the Pacific and Atlantic oceans (Pérez-Losada et al., 2004; Bueno et al., 2016).

The species $A$. concepcionensis has been poorly studied, with details about its biology or ecology mostly unknown, but it has been categorized as threatened. It is a benthic species that inhabits clean-water streams with sandy, quartzite-mycum substrates, mixed with leaf litter and woody detritus (Smith-Ramírez et al., 2005). It prefers areas of low depth and current speed but well oxygenated, since it has high oxygen demand (Bond-Buckup \& Buckup, 1994; Dalosto \& Santos, 2011). The geographical distribution of $A$. concepcionensis has also been little studied but it seems that, like other species of the genus Aegla, it has a relatively small distribution area. Most species in the genus are restricted to a single or a few drainage basins, which means they are highly endemic (Tumini et al., 2018). In particular, A. concepcionensis has been described as a micro-endemism, with a distribution area restricted to streams of the Biobío basin, around the city of Concepción (Jara, 1996, 2013; Bahamonde et al., 1998) 


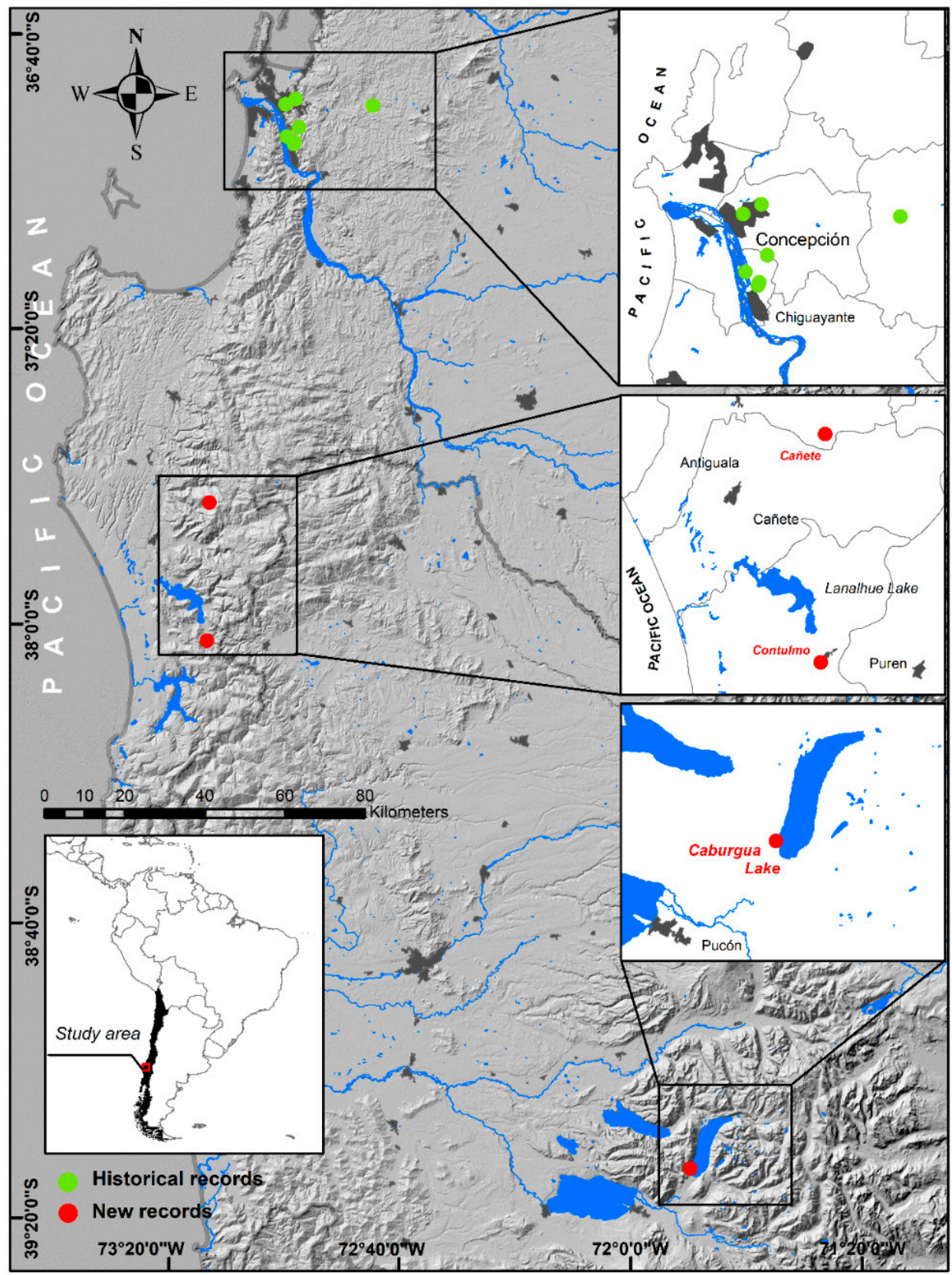

Figure 1. Geographical distribution of A. concepcionensis based on historical reports (Schmitt, 1940; Jara, 1996, 2013; Bahamonde et al., 1998; Oyanadel \& Valdovinos, 2004; MMA, 2013; Valdovinos, 2019) and new reports (this study). Distribución geográfica de A. concepcionensis basada en los reportes históricos (Schmitt, 1940; Jara, 1996, 2013; Bahamonde et al., 1998; Oyanadel \& Valdovinos, 2004; MMA, 2013; Valdovinos, 2019) y en los nuevos reportes (este estudio).

(Fig. 1). However, here we report the presence of this species at new sites outside this area and in a new type of habitat, thus extending its known range of geographical distribution and providing a more complete description of its habitat use. 


\section{MATERIALS AND METHODS}

\section{Study area and sampling strategy}

The study area corresponded to low-order streams located in the coastal area of the Chilean Mediterranean zone $\left(37^{\circ} 30^{\prime} 0^{\prime \prime} \mathrm{S}-38^{\circ} 0\right.$ ' 0 " $\left.\mathrm{S}\right)$ and one lacustrine ecosystem located in the lowlands of Andean Mountain range in Southern Chile (39 10' 46.70" S - 71 ${ }^{\circ} 48^{\prime} 35.84$ " O) (Fig. 1). Specifically, samples were collected from 10 streams: Quirilao 1 and 2, Piedra Laja, Contulmo 1, El Peral, Salto Rayén, Los Notros, Puente Mecano, El Canelo and Paillahue, and from Caburgua lake.

The studied streams are located in the Mediterranean coastal area of Chile, at the base of the Nahuelbuta mountain range. The climate is perhumid Mediterranean with a maritime influence, according to the classification of Di Castri \& Hajek (1976), with annual precipitation of $1294 \mathrm{~mm}$ and average annual temperature of $13.1^{\circ} \mathrm{C}$ (Luebert \& Pliscoff, 2006). The Nahuelbuta mountain range is formed by metamorphic rock from the Precambrian and Palaeozoic crystalline basement, as well as intrusive and volcanic rocks, mainly from the Tertiary and Quaternary. It presents a mountainous relief, with moderate to strong slopes and flat surfaces, reaching heights over $650 \mathrm{~m}$ a.s.l. The main economic activities of the area are tourism, small-scale agricultural and industrial forestry (Illustrious Municipality of Cañete, 2015).

The Caburgua lake, located in the foothills of the Andes, has a type of perhumid Mediterranean climate characterized by the presence of cool, mild summers and cold, wet winters. Annual rainfall is $2500 \mathrm{~mm}$ and average annual temperature is $12^{\circ} \mathrm{C}$ (Di Castri \& Hajek, 1976; CONAF, 1999). The Andean Mountain range is considered a large raised block, more than 2000 $\mathrm{m}$ a.s.l., made up of clastic-volcanic rocks from the Upper Cretaceous and by granites, on which volcanic rocks have been deposited during the Tertiary and Quaternary (IREN, 1970). It presents a mountainous relief, with very steep slopes and deep-water ecosystems due to the action of glaciations, which have deposited lateral moraines, and volcanism (Figueroa, 1983; CONAF, 1999). The main economic activity is tourism, followed by the agriculture and forestry (PRC, 2019).

In each stream, samples of benthic fauna $(\mathrm{n}=6)$ were collected during February (summer) and July (winter) of 2019, using a Surber net (30x30 cm; $250 \mu \mathrm{m}$ mesh). Each sample was taken for 5 minutes and including all the habitats present (Rodríguez-Capítulo et al., 2009; Santos et al., 2017). In the lake, the samples were taken manually at $3 \mathrm{~m}$ of depth through snorkelling in littoral zone. In both cases, the samples were in situ examined and individuals of the Aeglidae family were separated. We measured their total length $(\mathrm{cm})$, identified their sex, photographed them in high-resolution for later identification. Finally, the individuals were returned to their natural habitat.

\section{A. concepcionensis taxonomic identification}

The identification of the photographed specimens was done based on the Species Background file of the MMA (2014) used in the Regulation of Classification of species (CERs) and Jara (1996). All the diagnostic characters described in the literature (Schmitt, 1942) were compared, which include: an elongated triangular-linked face, with the rostral cavity crest containing two rows of small corneal scales; presence of a wide, protuberant and convex gastric area, with smooth shell side edges; predactilar lobe of the chelipods included in the palmar crest; antero-lateral angle of the second acute abdominal epimer containing an apical scale; and presence of a dimeric telson and pereiopods with blue-grey transverse bands interspersed with orange-yellow bands.

\section{Benthic macroinvertebrate sampling and analysis}

For the characterization of the benthic macroinvertebrate community to which Aegla concepcionensis was associated, streams were sampled during the summer and winter seasons, considering areas located at least $100 \mathrm{~m}$ upstream of bridges to avoid human intervention. The macroinvertebrate samples $(n=6)$ were extracted using a Surber net of $0.09 \mathrm{~m}^{2}$ area and $250 \mu \mathrm{m}$ mesh opening. To take samples, the Surber net was located upstream, washing the larger rocks in front 
of its entrance, and removing the thick substrate in order to extract the adhered individuals, in such a way that the organisms were dragged by the current to the bottom of the net (Figueroa et al., 2007; Correa-Araneda et al., 2021). The samples were previously cleaned in the field to remove the finest sediment, rocks, and woody material. They were later stored and transported to the laboratory in labelled plastic containers and fixed in $96 \%$ ethanol (Cornejo et al., 2019). We identified individuals to the family taxonomic level (Thorne \& Williams, 2003) using a trinocular stereoscopic magnifying glass (EUROMEX-HOLLAN NexiusZoom EVO NZ. 1903-PG), identification guides and keys (Flint, 1983; Peña, 1996; Roldán, 1996; Domínguez \& Fernández, 2001, 2009), as well as consultations with specialists.

\section{Benthic microalgal sampling and analysis}

To characterize the community of benthic microalgae, rocks were selected at random $(n=3)$ from the substrate of the streams. On the upper face of each rock a $1 \mathrm{~cm}^{2}$ quadrant was delimited, from which all the biofilm was extracted by scraping the attached microalgae. The material obtained was fixed with $5 \%$ lugol for subsequent taxonomic identification in the laboratory (Gómez et al., 2009). For identification, a gridded Sedgewick-Rafter (S-R) counting chamber was used, by means of the longitudinal transect method, where a minimum of 100 cells of the most abundant taxon present in each ocular field were counted. For the identification of diatoms, oxidations and permanent preparations were carried out (Gómez et al., 2009; APHA-AWWA-WEF, 2012). The microalgae were identified using the keys of Parra et al. (1982), Rivera (1983), Simonsen (1987), Krammer \& Lange-Bertalot (1991), Parra \& Bicudo (1996), Round \& Bukhtiyarova (1996) and bases updated international data (eg, https://www.algaebase.org, https://www.gbif.org).

\section{Habitat characterization}

To characterize the aquatic environment of $A$. concepcionensis we measured $\mathrm{pH}$, conductivity $(\mu \mathrm{S} /$ $\mathrm{cm})$, dissolved oxygen $(\mathrm{mg} / \mathrm{L})$, oxygen saturation $(\%)$, temperature $\left({ }^{\circ} \mathrm{C}\right)$, total suspended solids
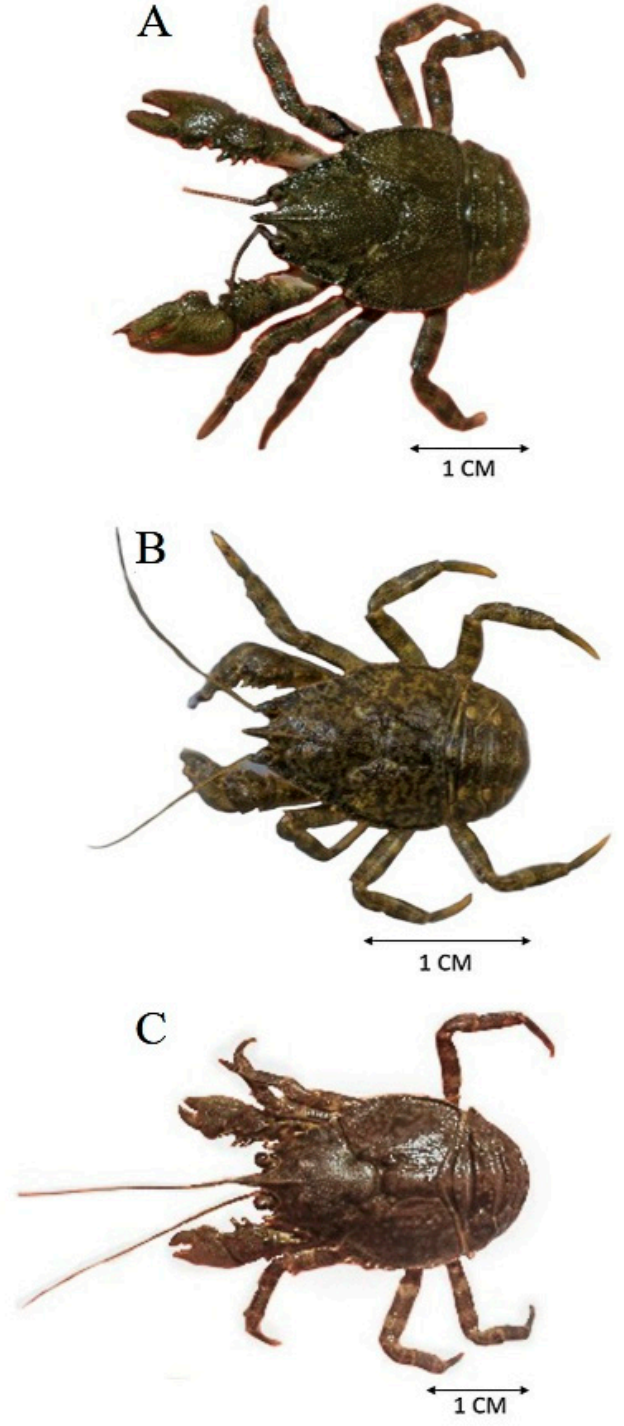

Figure 2. Images of adult's individuals of $A$. concepcionensis from Piedra Laja stream (A), Peral stream (B) and Caburgua lake (C). Imágenes de individuos adultos de A. concepcionensis provenientes del arroyo Piedra Laja (A), Arroyo Peral (B) y lago Caburgua (C).

(mg/L) and salinity (ppm) three times in situ with a multiparameter equipment (Hanna HI9829) in all sites where it was found; additionally, the physicochemical characteristic of the water were measured in winter and summer in streams and in summer in the lake. The depth $(\mathrm{cm})$ (streams and 
Table 1. Physicochemical ecosystem and atmospheric variables (mean, minimum and maximum values) of the new sites with the presence of $A$. concepcionensis. DO = Dissolved Oxygen, TSS = Total suspended solids. *rock walls. Variables fisicoquímicas y atmosféricas (promedio, mínimo y máximo) de los nuevos sitios con presencia de A. concepcionensis . DO = Oxígeno disuelto, TSS $=$ Sólidos suspendidos totales. *Paredes rocosas.

\begin{tabular}{|c|c|c|c|c|c|c|c|c|c|c|c|c|c|c|c|}
\hline \multirow{3}{*}{$\begin{array}{l}\text { Season } \\
\text { Physicochemical } \\
\text { ecosystem variables }\end{array}$} & \multicolumn{6}{|c|}{ Piedra Laja stream } & \multicolumn{6}{|c|}{ Peral stream } & \multirow{2}{*}{\multicolumn{3}{|c|}{$\begin{array}{r}\text { Caburgua lake } \\
\text { Summer }\end{array}$}} \\
\hline & \multicolumn{3}{|c|}{ Winter } & \multicolumn{3}{|c|}{ Summer } & \multicolumn{3}{|c|}{ Winter } & \multicolumn{3}{|c|}{ Summer } & & & \\
\hline & Mean & Min. & Max. & Mean & Min. & Max. & ean & Min. & Max. & Mean & Min. & Max. & \multicolumn{2}{|c|}{\begin{tabular}{lc}
\multicolumn{2}{r}{ Summe } \\
Mean Min.
\end{tabular}} & Max. \\
\hline Temperature $\left({ }^{\circ} \mathrm{C}\right)$ & 9.02 & 9.02 & 9.02 & 11.18 & 11.18 & 11.18 & 10.04 & 10.04 & 10.04 & 12.46 & 12.46 & 12.46 & 23.56 & 23.54 & 23.57 \\
\hline $\mathrm{DO}(\mathrm{mg} / \mathrm{L})$ & 17.31 & 17.14 & 17.34 & 16.78 & 16.73 & 16.86 & 17.62 & 17.54 & 17.66 & 13.41 & 13.38 & 13.43 & 8.50 & 7.8 & 9.10 \\
\hline Oxygen saturation (\%) & 150.23 & 147.5 & 154 & 152.73 & 152.2 & 153.5 & 155.27 & 155.2 & 155.4 & 125.60 & 125.2 & 126.1 & 115.3 & 90.40 & 118.50 \\
\hline Conductiv & 37.00 & 37.00 & 37.00 & 43.00 & 43.00 & 43.00 & 44.00 & 44.00 & 44.00 & 38.00 & 38.00 & 38.00 & 38.00 & 38.00 & 38.00 \\
\hline Salinit & 0.02 & 0.02 & 0.02 & 0.02 & 0.02 & 0.02 & 0.02 & 0.02 & 0.02 & 0.02 & 0.02 & 0.02 & 0.02 & 0.02 & 0.02 \\
\hline $\mathrm{pH}$ & 7.22 & 7.18 & 7.26 & 6.51 & 6.51 & 6.53 & 6.72 & 6.7 & 6.73 & 6.70 & 6.69 & 6.70 & 7.68 & 7.66 & 7.69 \\
\hline $\mathrm{TSS}(\mathrm{mg} / \mathrm{L})$ & 19.00 & 19 & 19 & 22.00 & 22.00 & 22.00 & 22.00 & 22.00 & 22.00 & 19.00 & 19.00 & 19.00 & 19.00 & 19.00 & 19.00 \\
\hline Deptl & 0.25 & 0.10 & 0.40 & 0.19 & 0.06 & 0.3 & 0.23 & 0.05 & 0.35 & 0.05 & 0.03 & 0.07 & 3.00 & 2.5 & 10 \\
\hline Widtl & 2.25 & 1 & 4 & 1.20 & 0.4 & 1.6 & 1.25 & 0.5 & 2.5 & 0.70 & 0.2 & 1.2 & - & - & - \\
\hline Veloc & 0.23 & 0.02 & 0.48 & 0.09 & 0.04 & 0.19 & 0.36 & 0.02 & 1.08 & 0.32 & 0.02 & 0.5 & - & - & - \\
\hline Flow $\left(\mathrm{m}^{3} / \mathrm{s}\right)$ & 0.25 & 0.012 & 0.58 & 0.03 & 0.001 & 0.05 & 0.14 & 0.002 & 0.33 & 0.01 & 0.001 & 0.04 & - & - & - \\
\hline $\mathrm{e}(\mathrm{cm})$ & 25 & 15 & 35 & 25 & 15 & 35 & 25 & 15 & 35 & 25 & 15 & 35 & 250 & 200 & $300^{*}$ \\
\hline $\begin{array}{l}\text { Habitat kind } \\
\text { Atmospheric } \\
\text { variables } \\
\end{array}$ & & Natural & & & Natural & & & Natural & & & Natural & & & Natural & \\
\hline Mean Temperature $\left({ }^{\circ} \mathrm{C}\right)$ & 8.48 & 0.00 & 14.00 & 13.57 & 5.3 & 24.3 & 7.92 & -2.2 & 17.5 & 15.76 & 0.8 & 34.1 & 15.98 & 2.5 & 16.4 \\
\hline Relat & 83.49 & 62.6 & 96 & 73.23 & 63.2 & 89.8 & 82.38 & 71.3 & 90.6 & 67.30 & 59 & 87.1 & 69.69 & 41.3 & 85.9 \\
\hline $\begin{array}{l}\text { Accumulated } \\
\text { precipitation }(\mathrm{mm})\end{array}$ & 8.18 & 0 & 62.7 & 0.56 & 0 & 16.7 & 4.23 & 0 & 39.8 & 0.44 & 0.00 & 11.1 & 3.74 & 0.00 & 49.10 \\
\hline Atmospheric pressure (mbar) & 1055 & 1040 & 1066 & 1014 & 1010 & 1018 & 1013 & 998 & 1024 & 1009 & 1005 & 1014 & 983.33 & 978 & 987 \\
\hline Solar radiation $\left(\mathrm{Mj} / \mathrm{m}^{2}\right)$ & 7.14 & 0.2 & 13.6 & 25.26 & 6.3 & 30.2 & - & - & - & - & - & - & & & \\
\hline Wind speed $(\mathrm{km} / \mathrm{h})$ & 6.82 & 0.5 & 14.7 & 7.14 & 3.5 & 11.2 & 3.23 & 0.1 & 11.6 & 5.75 & 2.1 & 10.5 & 3.93 & 1.9 & 9.4 \\
\hline
\end{tabular}

lake), width $(\mathrm{cm})$, speed $(\mathrm{m} / \mathrm{s})$ and flow $\left(\mathrm{m}^{3} / \mathrm{s}\right)$ at each stream site were also determined. To characterize the riparian vegetation, we used an adaptation of the methodology described by Vidal (2005), which consists of registering vascular species adjacent to the watercourse, considering a $10 \mathrm{~m}$ transect perpendicular to each riverbank. Vascular plant species were identified using Vidal (2005). The climatic variables mean temperature (Tm), maximum (Tmax), and minimum (Tmin), relative humidity (HR), accumulated precipitation (PPT), atmospheric pressure (mbar), ultraviolet solar radiation $\left(\mathrm{Mj} / \mathrm{m}^{2}\right)$ and wind speed $(\mathrm{km} / \mathrm{h}$; Table 1$)$ of the sampling month, were obtained from the environmental databases of the INIA (2020), in order to analyse the environment with which aquatic organisms interact directly or indirectly (Schaefer et al., 2008).

\section{Statistical analyses}

The community structure of the benthos (macroinvertebrates and microalgae) was analysed using the indices of taxonomic richness (S), total abundance (N), Shannon diversity (H'), and Palou's evenness index (J') (Krebs, 1988). Community indexes were calculated for each community using Primer V.6 software (Diverse analysis; Clarke $\&$ Gorley, 2006). To compare the mean range of the related samples and determine the existence of significant differences the Wilcox test was used $(p<0.05)$. This analysis was carried out with function in the $\mathrm{R}$ agricolae package (Mendiburu, 2020).

\section{RESULTS}

We found 4 specimens of $A$. concepcionensis in Caburgua lake and in 2 out of the 10 streams stud- 
Table 2. Presence/absence matrix and phytogeography origin (P.O.; $\mathrm{N}=$ Native, $\mathrm{E}=$ Exotic) of riparian vegetation in sites with pres-

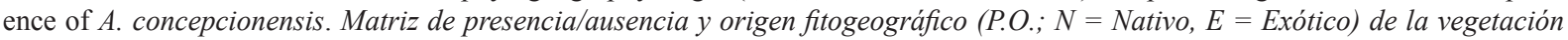
rivereña en los sitios con presencia de A. concepcionensis .

\begin{tabular}{|c|c|c|c|c|}
\hline Taxa & Piedra Laja stream & Peral stream & Caburgua lake & P.O. \\
\hline $\begin{array}{l}\text { Aextoxicaceae } \\
\text { Aextoxicon punctatum Ruiz \& Pav. } \\
\text { Blechnaceae }\end{array}$ & $\mathrm{X}$ & & & $\mathrm{N}$ \\
\hline Blechnum hastatum Kaulf. & $\mathrm{X}$ & $\mathrm{X}$ & & $\mathrm{N}$ \\
\hline Blechnum mochaenum $\mathrm{G}$. Kunkel & $\mathrm{X}$ & $\mathrm{X}$ & & $\mathrm{N}$ \\
\hline $\begin{array}{l}\text { Blechnum chilense (Kaulf.) Mett. } \\
\text { Celastraceae }\end{array}$ & $\mathrm{X}$ & & & $\mathrm{N}$ \\
\hline $\begin{array}{l}\text { Maytenus boaria Molina } \\
\text { Ciperaceae }\end{array}$ & & & $\mathrm{X}$ & $\mathrm{N}$ \\
\hline $\begin{array}{l}\text { Carex sp. } \\
\text { Dicksoniaceae }\end{array}$ & $\mathrm{X}$ & & & $\mathrm{N}$ \\
\hline Lophosoria quadripinnata (J.F. Gmel.) C. Chr. & $\mathrm{X}$ & & & $\mathrm{N}$ \\
\hline $\begin{array}{l}\text { Dryopteridaceae } \\
\text { Megalastrum spectabile (Kaulf.) A.R. Sm. \& R.C. } \\
\text { Moran } \\
\text { Elaeocarpaceae }\end{array}$ & $\mathrm{X}$ & & & $\mathrm{N}$ \\
\hline $\begin{array}{l}\text { Aristotelia chilensis (Molina) Stuntz } \\
\text { Ericaceae }\end{array}$ & $\mathrm{X}$ & $\mathrm{X}$ & $\mathrm{X}$ & $\mathrm{N}$ \\
\hline $\begin{array}{l}\text { Gaultheria mucronata (L. f.) Hook. \& Arn. } \\
\text { Eucryphiaceae }\end{array}$ & $\mathrm{X}$ & & & $\mathrm{N}$ \\
\hline $\begin{array}{l}\text { Eucryphia cordifolia } \text { Cav. } \\
\text { Lardizabalaceae }\end{array}$ & & & $\mathrm{X}$ & $\mathrm{N}$ \\
\hline $\begin{array}{l}\text { Boquila trifoliolata (DC.) Decne. } \\
\text { Loranthaceae }\end{array}$ & $\mathrm{X}$ & $\mathrm{X}$ & & $\mathrm{N}$ \\
\hline $\begin{array}{l}\text { Tristerix corymbosus (L.) Kuijt } \\
\text { Monimiaceae }\end{array}$ & $\mathrm{X}$ & & & $\mathrm{N}$ \\
\hline $\begin{array}{l}\text { Peumus boldus Molina } \\
\text { Myrtaceae }\end{array}$ & & $\mathrm{X}$ & $\mathrm{X}$ & $\mathrm{N}$ \\
\hline Eucalyptus globulus Labill. & $\mathrm{X}$ & $\mathrm{X}$ & & $\mathrm{E}$ \\
\hline $\begin{array}{l}\text { Luma apiculata (DC.) Burret } \\
\text { Nothofagaceae }\end{array}$ & $\mathrm{X}$ & & $\mathrm{X}$ & $\mathrm{N}$ \\
\hline Nothofagus obliqua (Mirb.) Oerst. & $\mathrm{X}$ & $\mathrm{X}$ & $\mathrm{X}$ & $\mathrm{N}$ \\
\hline $\begin{array}{l}\text { Nothofagus dombeyi (Mirb.) Oerst } \\
\text { Onagraceae }\end{array}$ & & & $\mathrm{X}$ & $\mathrm{N}$ \\
\hline $\begin{array}{l}\text { Fuchsia magellanica Lam. } \\
\text { Oleaceae }\end{array}$ & $\mathrm{X}$ & & $\mathrm{X}$ & $\mathrm{N}$ \\
\hline $\begin{array}{l}\text { Fraxinus sp. } \\
\text { Philesiaceae }\end{array}$ & & & $\mathrm{X}$ & E \\
\hline $\begin{array}{l}\text { Lapageria rosea Ruiz \& Pav. } \\
\text { Pinaceae }\end{array}$ & $\mathrm{X}$ & $\mathrm{X}$ & & $\mathrm{N}$ \\
\hline $\begin{array}{l}\text { Pinus radiate D. Don } \\
\text { Poaceae }\end{array}$ & $\mathrm{X}$ & $\mathrm{X}$ & & $\mathrm{E}$ \\
\hline $\begin{array}{l}\text { Chusquea quila Kunth } \\
\text { Polypodiaceae }\end{array}$ & $\mathrm{X}$ & $\mathrm{X}$ & $\mathrm{X}$ & $\mathrm{N}$ \\
\hline $\begin{array}{l}\text { Synammia feuillei (Bertero) Copel. } \\
\text { Proteaceae }\end{array}$ & $\mathrm{X}$ & & & $\mathrm{N}$ \\
\hline $\begin{array}{l}\text { Gevuina avellana Molina } \\
\text { Rosaceae }\end{array}$ & & & $\mathrm{X}$ & $\mathrm{N}$ \\
\hline $\begin{array}{l}\text { Rubus ulmifolius Schott } \\
\text { Rubiaceae }\end{array}$ & $\mathrm{X}$ & $\mathrm{X}$ & $\mathrm{X}$ & $\mathrm{E}$ \\
\hline $\begin{array}{l}\text { Nertera granadensis (Mutis ex L.f.) Druce } \\
\text { Salicaceae }\end{array}$ & & $\mathrm{X}$ & & $\mathrm{N}$ \\
\hline $\begin{array}{l}\text { Populus sp. } \\
\text { Urticaceae }\end{array}$ & & & $\mathrm{X}$ & $\mathrm{E}$ \\
\hline $\begin{array}{l}\text { Pilea elegans Gay } \\
\text { Verbenaceae }\end{array}$ & $\mathrm{X}$ & & & $\mathrm{N}$ \\
\hline $\begin{array}{l}\text { Rhaphithamnus spinosus (Juss.) Moldenke } \\
\text { Vitaceae }\end{array}$ & $\mathrm{X}$ & & & $\mathrm{N}$ \\
\hline Cissus striata Ruiz \& Pav. & $\mathrm{X}$ & $\mathrm{X}$ & & $\mathrm{N}$ \\
\hline
\end{tabular}


ied, which correspond to the Piedra Laja and Peral streams. We found 2 males at the first stream, 1 female at the second and 1 female in the Caburgua lake (Fig. 2). The male specimens had an average cephalothorax length of $1.52+0.45 \mathrm{~cm}$, while the female specimens had an average cephalothorax length of $0.7+0.14 \mathrm{~cm}$.

Water physicochemistry in the summer and winter at the 2 streams were $A$. concepcionensis was collected were the following: temperature, 9.02-12.46 ${ }^{\circ} \mathrm{C} ; \mathrm{pH}, 6.51-7.22$, oxygen concentration, 13.41-17.62 mg/L; oxygen saturation, $125.6-$ $155.27 \%$; conductivity, 37-44 $\mu \mathrm{S} / \mathrm{cm}$; salinity, $0.02 \mathrm{ppm}$ and total suspended solid concentra- tion, 19-22 mg/L (Table 1). In Caburgua lake the average values of the physicochemical variables of the water in the summer were: temperature, $23.56 \pm 0.02{ }^{\circ} \mathrm{C} ; \mathrm{pH}, 7.68 \pm 0.02$; oxygen concentration, $8.50 \pm 0.06 \mathrm{mg} / \mathrm{L}$; oxygen saturation, $115.3 \pm 7.83 \%$; conductivity, $38 \pm 0.00 \mu \mathrm{S} / \mathrm{cm}$; salinity, $0.02 \pm 0.00 \mathrm{ppm}$ and total suspended solid concentration, $19.00 \pm 0.00 \mathrm{mg} / \mathrm{L}$ (Table 1). Regarding the depth (streams and lakes) and the water velocity (streams), the average values of the sites studied according to the season (winter and summer) are presented in Table 1. The riparian vegetation at these 3 sites consisted of 31 species, of which $83.9 \%$ were native and $16.1 \%$
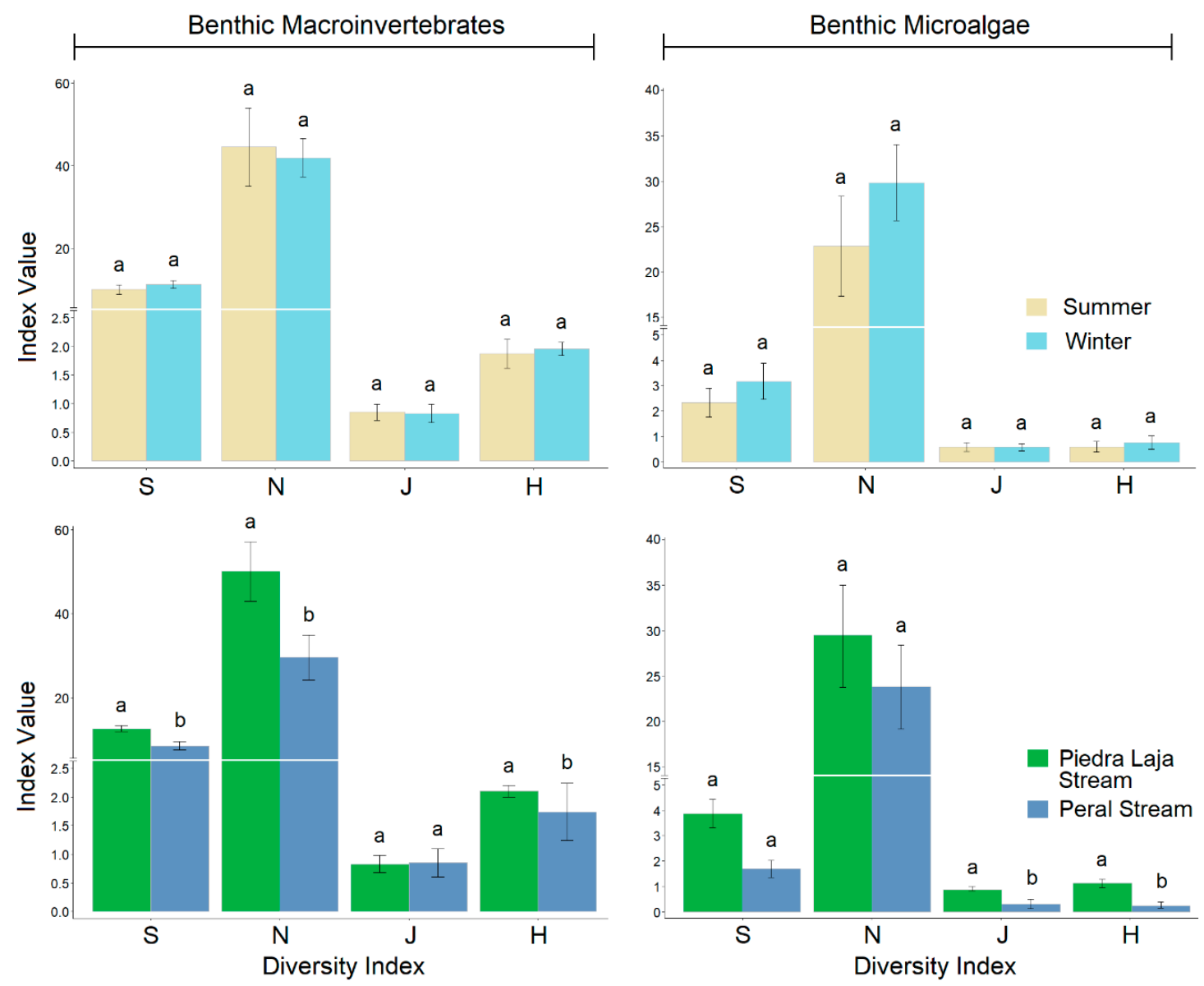

Figure 3. Indices of the macroinvertebrate (left) and microalgae (right) benthic communities recorded in the streams for seasons (upper) and sampling sites (lower), different letters indicate statistically significant differences. Índices comunitarios de macroinvertebrados (izquierda) y microalgas (derecha) bentónicas registradas en los arroyos por estaciones (superior) y sitios de muestreo (inferior), letras diferentes indican diferencias estadisticamente significativas $(\mathrm{p}<0.05)$. 
exotic (Table 2). We registered 23, 13 and 13 plant species at the Piedra Laja stream, Peral stream and Caburgua lake respectively, of which 11 species were common between streams and 4 taxa between all sites. The most abundant families were Blechnaceae, Myrtaceae and Nothofagaceae (Table 2).

The climatic variables in summer and winter in the streams where A. concepcionensis were collected are the following: average temperature, 7.92-15.76 ${ }^{\circ} \mathrm{C}$; relative humidity, 67.3-83.49\%; precipitation accumulation, $0.44-8.18 \mathrm{~mm}$; atmospheric pressure, 1009-1055 mbar; solar radiation, 7.14-25.26 Mj/m²; wind speed, 3.23$7.14 \mathrm{~km} / \mathrm{h}$ (Table 1). Caburgua lake in the summertime registered: average temperature of $15.98^{\circ} \mathrm{C}$; relative humidity, $69.69 \%$; precipitation accumulation, $3.74 \mathrm{~mm}$; atmospheric pressure, $983.33 \mathrm{mbar}$; wind speed, $3.93 \mathrm{~km} / \mathrm{h}$ (Table 1).

In summer season, in the Piedra Laja and Peral streams, respectively, showed a macroinvertebrate taxonomic richness of 12 and 8, an abundance of 66.17 and 22.8 individuals $/ 0.09 \mathrm{~m}^{2}$, a diversity of Shannon of 2.08 and 1.68, and an evenness of 0.85 in both. In the winter season the richness was 13 and 9, abundance was 47.5 and 36.3 individuals $/ 0.09 \mathrm{~m}^{2}$, Shannon diversity was 2.13 and 1.8 and evenness was 0.82 and 0.85 (Table 3; Fig. 3-left). Results from the Wilcox test showed that macroinvertebrate community was similar among seasons (Fig. 3-left) and different among sampling sites, showed statistically differences in the $\mathrm{S}, \mathrm{N}$ and $\mathrm{H}$ indexes (Fig. 3-left). For microalgae, in the summer season the above streams showed a taxonomic richness of 3 and 1, an abundance of 31.3 and $14.3 \mathrm{cel} / \mathrm{cm}^{2}$, a Shannon diversity of 0.98 and 0.21 , and an evenness of 0.85 and 0.31 . In the winter season, taxonomic richness was 4 and 2, abundance was 27 and $33 \mathrm{cel} / \mathrm{cm}^{2}$, Shannon diversity was 1.22 and 0.3 , and evenness 0.83 and 0.32 (Table 4; Fig. 3-right). Results from the Wilcox test showed that microalgae community was similar among seasons (Fig. 3-right) and different among sampling sites, showed statistically differences in the $\mathrm{J}$ and $\mathrm{H}$ indexes (Fig. 3-right).

\section{DISCUSSION}

A. concepcionensis had been previously described as a micro-endemic species with its geographical distribution limited to the Biobío region in Chile (Bahamonde et al., 1998; Jara, 2013). The first record of the species was made by Schmitt (1940) in the city of Concepción. Then Jara (1996) described its presence in the Villa Vergara and Nonguén streams, a stream flowing into the Pineda Lagoon, and a stream and waterfall in the campus of the University of Concepción. Bahamonde et al. (1998) reported its presence in the Andalién river basin and confirmed the distribution described by Jara (1996). Oyanadel \& Valdovinos (2004) reported its presence in the Cárcamo stream, which is located within the grounds of the Universidad de Concepción. Subsequently, Jara (2005) suggested that it could be present in a stream at the Cayumanqui hill (Quillón), bit he could not confirm it. The MMA (2013) reported the presence of the species in the Lircay and San Onofre streams and in a tributary of San Onofre. The same year, Jara (2013) confirmed the distribution described in 1996 and added the Manantiales and Estadio Árabe streams in Chiguayante city. Finally, Valdovinos (2019) corroborated its presence in different areas of the Andalién river basin, including the lower middle course of the Andalién River, the Nonguén stream, the Laguna Pineda and streams in the Cayumanqui hill.

All the above reports supported the micro-endemism of the species to the Andalién river basin, in the surroundings of Concepción city (Jara, 1996, 2013; Bahamonde et al., 1998; Valdovinos, 2019). However, our results show a wider geographical distribution of the species, as we recorded its presence in streams and one lake located ca. $120 \mathrm{~km}$ and $270 \mathrm{~km}$ respectively at south of the limit previously described, in completely disconnected basins, which correspond to an extension of the known distribution range. The streams where we found $A$. concepcionensis are part of short river basins that drain towards the Pacific from the Nahuelbuta mountain range at the height of the Cañete and Contulmo cities, the streams where A. concepcionensis was collected drain towards Lanalhue lake, whose origin is tectonic (Stefer et al., 2010). The Caburgua lake, it's located in the base of Andean Mountain range, has a glacial origin, absence of industrial or agricultural activities and oligotrophic waters. Never- 
Table 3. Abundance $\left(\mathrm{N}^{\circ}\right.$ ind $\left./ 0.09 \mathrm{~m}^{2}\right)$ of benthic macroinvertebrates in sites with presence of A. concepcionensis. Abundancia de macroinvertebrados bentónicos en los sitios con presencia de A. concepcionensis .

\begin{tabular}{|c|c|c|c|c|}
\hline \multirow[b]{2}{*}{ Taxa } & \multicolumn{2}{|c|}{ Piedra Laja stream } & \multicolumn{2}{|c|}{ Peral stream } \\
\hline & Winter & Summer & Winter & Summer \\
\hline \multicolumn{5}{|l|}{ Tricladida } \\
\hline Dugesidae & $0.015 \pm 0.036$ & & & \\
\hline Oligochaeta & $0.165 \pm 0.237$ & & $0.06 \pm 0.109$ & \\
\hline Lombriculidae & & $0.48 \pm 0.25$ & & \\
\hline \multicolumn{5}{|l|}{ Gastropoda } \\
\hline Amnicolidae & $0.15 \pm 0.32$ & $0.285 \pm 0.453$ & & $0.27 \pm 0.34$ \\
\hline Chilinidae & & $0.03 \pm 0.07$ & & \\
\hline \multicolumn{5}{|l|}{ Bivalvia } \\
\hline Sphariidae & & & $0.015 \pm 0.036$ & \\
\hline \multicolumn{5}{|l|}{ Amphipoda } \\
\hline Hyalellidae & $0.03 \pm 0.07$ & & & \\
\hline \multicolumn{5}{|l|}{ Ephemeroptera } \\
\hline Leptophlebiidae & $0.765 \pm 0.562$ & & $0.705 \pm 0.453$ & $0.015 \pm 0.033$ \\
\hline Siphlonuridae & $0.105 \pm 0.119$ & & $0.135 \pm 0.203$ & \\
\hline Baetidae & $0.285 \pm 0.216$ & $0.12 \pm 0.15$ & $0.045 \pm 0.049$ & \\
\hline Coloburiscidae & & & & $0.015 \pm 0.033$ \\
\hline \multicolumn{5}{|l|}{ Plecoptera } \\
\hline Gripopterygidae & $0.105 \pm 0.183$ & & $0.66 \pm 0.35$ & $0.03 \pm 0.04$ \\
\hline Perlidae & $0.12 \pm 0.13$ & & $0.015 \pm 0.036$ & $0.165 \pm 0.141$ \\
\hline Eustheniidae & $0.06 \pm 0.07$ & $0.015 \pm 0.036$ & & $0.03 \pm 0.06$ \\
\hline Austroperlidae & & & & $0.075 \pm 0.08$ \\
\hline Diamphipnoidae & $0.045 \pm 0.075$ & $0.315 \pm 0.246$ & $0.18 \pm 0.24$ & $0.015 \pm 0.033$ \\
\hline Notonemouridae & $0.24 \pm 0.21$ & & $0.15 \pm 0.21$ & \\
\hline \multicolumn{5}{|l|}{ Trichoptera } \\
\hline Limnephilidae & $0.015 \pm 0.036$ & & $0.015 \pm 0.036$ & \\
\hline Sericostomatidae & $0.705 \pm 0.477$ & $1.305 \pm 0.675$ & $0.33 \pm 0.32$ & $0.24 \pm 0.31$ \\
\hline Leptoceridae & $0.015 \pm 0.036$ & $0.075 \pm 0.119$ & $0.015 \pm 0.036$ & \\
\hline Hydroptilidae & & & & $0.015 \pm 0.033$ \\
\hline Hydropsichidae & $0.945 \pm 0.320$ & $1.02 \pm 1.31$ & $0.27 \pm 0.53$ & $0.105 \pm 0.096$ \\
\hline Ecnomidae & & $0.045 \pm 0.075$ & & $0.06 \pm 0.13$ \\
\hline Philopotamidae & $0.045 \pm 0.049$ & & $0.015 \pm 0.036$ & \\
\hline Odontoceridae & $0.015 \pm 0.036$ & & & \\
\hline Anomalopsichidae & $0.03 \pm 0.04$ & & $0.03 \pm 0.04$ & $0.15 \pm 0.29$ \\
\hline Helicopsichidae & $0.015 \pm 0.036$ & $0.12 \pm 0.29$ & & \\
\hline Calamoceratidae & $0.015 \pm 0.036$ & & $0.075 \pm 0.088$ & \\
\hline Glossosomatidae & $0.045 \pm 0.049$ & & & \\
\hline \multicolumn{5}{|l|}{ Coleoptera } \\
\hline Psephenidae & $0.015 \pm 0.036$ & $0.42 \pm 0.43$ & & \\
\hline Elmidae & $0.09 \pm 0.13$ & $0.51 \pm 0.40$ & & \\
\hline
\end{tabular}


Table 3. (cont.)

\begin{tabular}{|c|c|c|c|c|}
\hline \multirow[b]{2}{*}{ Taxa } & \multicolumn{2}{|c|}{ Piedra Laja stream } & \multicolumn{2}{|c|}{ Peral stream } \\
\hline & Winter & Summer & Winter & Summer \\
\hline \multicolumn{5}{|l|}{ Diptera } \\
\hline Chironomidae & $0.075 \pm 0.067$ & $0.57 \pm 0.37$ & $0.045 \pm 0.11$ & $0.135 \pm 0.135$ \\
\hline Athericidae & & $0.135 \pm 0.124$ & & $0.105 \pm 0.12$ \\
\hline Simulidae & $0.045 \pm 0.049$ & $0.225 \pm 0.246$ & $0.45 \pm 0.6$ & $0.015 \pm 0.033$ \\
\hline Ceratopogonidae & & $0.03 \pm 0.04$ & & $0.015 \pm 0.033$ \\
\hline Dixydae & & & $0.015 \pm 0.036$ & \\
\hline Limoniidae & $0.06 \pm 0.07$ & & & $0.48 \pm 0.394$ \\
\hline Tipulidae & $0.015 \pm 0.036$ & & $0.03 \pm 0.04$ & \\
\hline Empididae & & & & $0.015 \pm 0.033$ \\
\hline \multicolumn{5}{|l|}{ Megaloptera } \\
\hline Corydalidae & $0.015 \pm 0.036$ & $0.09 \pm 0.13$ & & $0.09 \pm 0.07$ \\
\hline \multicolumn{5}{|l|}{ Odonata } \\
\hline Libellulidae & & $0.045 \pm 0.11$ & & $0.015 \pm 0.033$ \\
\hline \multicolumn{5}{|l|}{ Entognata } \\
\hline Collembola & $0.015 \pm 0.036$ & & & \\
\hline Hirudinea & & $0.03 \pm 0.07$ & & \\
\hline \multicolumn{5}{|l|}{ Arachnida } \\
\hline Acari & & $0.03 \pm 0.04$ & & \\
\hline \multicolumn{5}{|l|}{ Decapoda } \\
\hline Aeglidae & $0.015 \pm 0.036$ & $0.06 \pm 0.07$ & & \\
\hline N.N. & & & & \\
\hline
\end{tabular}

theless, in the summer season it is one of the most visited natural places in south of Chile for the practice of touristic activities, which, depending on their intensity and type (motor boats), could be generating negative effects in this population (Fig. 1). The species has probably always inhabited these sites without being discovered, which evidences the scarce knowledge of the benthic fauna of fresh waters in southern Chile.

Regarding morphology, some reports indicate that its maximum length (from the end of the rostrum to the posterior edge of the cephalothorax) is $3.3 \mathrm{~cm}$ in males and $2.3 \mathrm{~cm}$ in females, which is consistent with the sexual dimorphism reported for the genus (Burns, 1972; Jara, 1996). It is potentially omnivorous, since it feeds on carrion and detritus accumulated in the substrate, and it is possibly preyed upon by native birds such as Ceryle torquata (ringed kingfisher) and introduced fish such as Oncorhynchus mykiss (rainbow trout) and Salmo trutta (brown trout), both species are of Eurasian origin, with a fairly aggressive, opportunistic behaviour, flexibility and phenotypic plasticity (Burns, 1972; Arenas, 1978; Palma et al., 2002; Bond-Buckup et al., 2008; Arismendi et al. 2012; Ayllón et al., 2021).

The ecology of $A$. concepcionensis is mostly unknown, which is critical in order to establish its real conservation status, which has undergone several changes over time: Bahamonde et al. (1998) first categorized the species as vulnerable; Pérez-Losada et al. (2002) suggested it should be classified as extinct in the wild; Jara (2005) described it as endangered and declared it extinct around the city of Concepción; Pérez-Losada et al. (2009) classified it as a critically endangered; and the MMA (2014) categorized it as endangered, this being its current classification. Studies 
Table 4. Abundance $\left(\mathrm{N}^{\circ} \mathrm{cel} / \mathrm{cm}^{2}\right)$ of benthic microalgae in sites with presence of $A$. concepcionensis. $\mathrm{DO}=\mathrm{Dissolved} \mathrm{Oxygen,} \mathrm{TSS}=$ Total suspended solids. *rock walls. Abundancia de microalgas bentónicas en los sitios con presencia de A. concepcionensis.

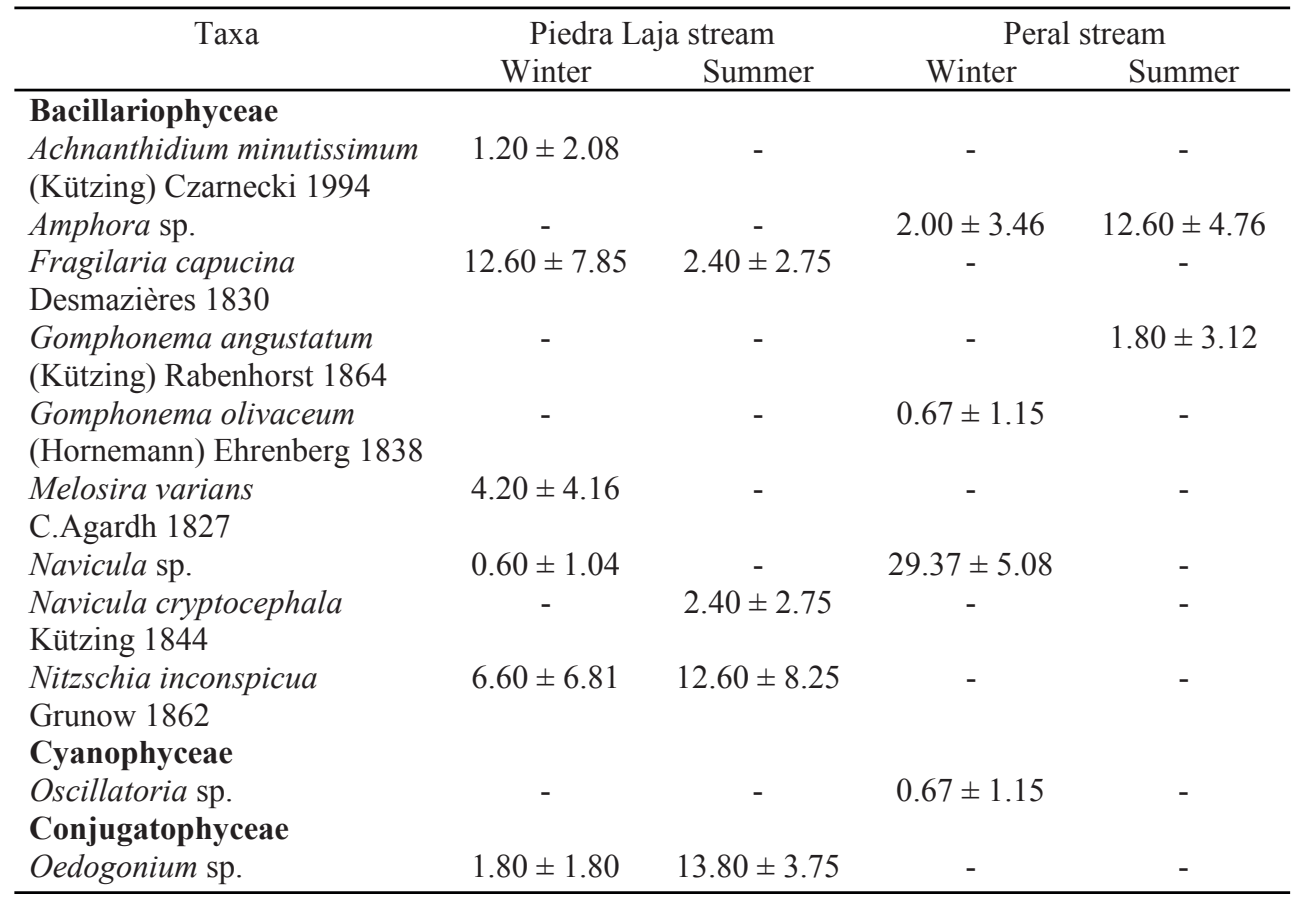

that address the classification of the conservation status of the species are scarce and restricted to a reduced geographical area, the product of which has had so many modifications. However, based on our results, we propose to maintain its current classification, due to the context of anthropic intervention, mainly related to forestry monoculture and intensive tourism activities. For this reason, it is necessary to implement measures to protect these ecosystems.

Regarding the habitat use of $A$. concepcionensis, our study suggests that it inhabits areas with low human intervention, where the riparian forest is dominated by native species (Table 2). This might be related to the fact that this vegetation allows a lower and more stable water temperature than outside the canopy, provides constant inputs of allochthonous organic matter that serve as food for this species and many other in the benthic community (Tables 3 and 4), and allows the multifunctionality of stream ecosystems to be maintained (López-Rojo et al., 2019).
Similarly, Jara (2005) and Valdovinos (2019) reported the greatest abundance of specimens of this species in areas with more allochthonous plant litter inputs at the Cárcamo stream (University of Concepción).

We found that $A$. concepcionensis used shallow waters, both streams and lakes, which remain well oxygenated throughout the year, probably because it has high oxygen demand like other species of the Aeglidae family (Jara, 2005; Dalosto $\&$ Santos, 2011). This is consistent with the results obtained by MMA (2013), who described the presence of the species in a stream of moderate current with oxygen concentration and saturation of $9.15 \mathrm{mg} / \mathrm{L}$ and $93.8 \%$, respectively. In relation to its thermal regime, our results suggest that the species use cold and temperate waters (9.02-23.46 ${ }^{\circ} \mathrm{C}$ ), also in accordance with MMA (2013), which reported the presence of the species at $15.5{ }^{\circ} \mathrm{C}$. Ideally, experimental studies should corroborate its range of thermal tolerance, which would allow to project the possible sites suitable for the distri- 
bution of the species and the potential effects of climate change on its distribution range.

Rallo \& García-Arberas (2002), established that conductivity $(\mu \mathrm{S} / \mathrm{cm}), \mathrm{pH}$ and $\mathrm{NO}^{-}$and PO4-, directly influence decapod biology. They also showed that the optimal values of these mentioned chemical variables should range between 41-891 $\mu \mathrm{S} / \mathrm{cm}$, and between 7.3-8.9 $\mathrm{pH}$ (Rallo et al., 2004). These reports are consistent with the conductivity and $\mathrm{pH}$ values recorded in the streams and lake studied (Table 1).

We found that the species use streams with neutral $\mathrm{pH}$ - which is consistent with that reported by MMA (2013) - and low conductivity, which indicates low human impact. Additionally, the high diversity of macroinvertebrate and microalgal benthic communities at the same sites supports their low intervention (Tables 3 and 4). Jara (2005) indicated that the species has probably disappeared around the city of Concepción during the last decade, as a result of the conjunction of intense forest fires, summer droughts (due to the destruction of native forest and climate warming) and the contamination of the water bodies by sewage discharge. There are, however, no specific studies that have related these stressors to population responses.

Potential risks for the species include practices for the maintenance of reservoirs, which contribute to the alteration of the dynamic's natural channels such as abnormal sediment supply. Alterations in the continuity of water flow and sudden increase in flow; and the destruction of native forest due to fires, or in favour of agriculture of plantations, which significantly affects nutrient cycles and the dynamics of aquatic communities (López-Rojo et al., 2019). On this basis, it would be necessary more ecological studies, that involves habitats density in different ecosystems for understand its behaviour such as has been described for other species of Aegla genus (De los Ríos-Escalante, 2017; De los Ríos-Escalante et al., 2019). Also, it is necessary more studies about distribution of Aegla genus considering their biogeography at regional scales (De los Ríos-Escalante et al., 2013). Based on our study and those cited above, we conclude that its previous and restricted known distribution range is mainly due to, scarce studies, low sampling effort and/or misidentifications due to lack of specialists. Particularly relevant is that, due to the current good state of conservation of its habitat in the new sites described, anthropic intervention should be minimized; especially those areas associated with urban expansion and pollutants touristic activities towards the streams and lakes.

\section{ACKNOWLEDGMENTS}

We thank Maria Elisa Diaz for manuscript revision. This study was supported by: 'FONDECYT de Iniciación’ Project No. 11170390 (CONICYT, Chile), and MECESUP UCT, it recognized the valuable suggestions of M.I. and S.M.A for improve the manuscript. Student support came from CONICYT-PFCHA/Magíster Nacional/ 2020-22200247 scholarship to GFM.

\section{REFERENCES}

APHA-AWWA-WEF. (2012). Standard Methods for the Examination of Water and Wastewater. 22th Edition. Washington DC. USA.

Arenas, J. (1978). Análisis de la alimentación de Salmo gairdnieri (Richardson) en el lago Riñihue y río San Pedro, Chile. Medio Ambiente, $3(2), \quad 50-58$. http://bibliotecadigital.ciren.cl/ handle/123456789/24824

Arismendi, I., González, J., Soto, D. \& Penaluna, B. (2012). Piscivory and diet overlap between two non-native fishes in southern Chile streams. Austral Ecology, 37, 346-354. DOI: 10.1111/j.1442-9993.2011.02282.x

Ayllón, D., Nicola, G. G., Elvira, B. \& Almodóvar, A. (2021). Climate change will render size-selective harvest of cold-water fish species unsustainable in Mediterranean freshwaters. Journal of Applied Ecology, 58, 562-575. DOI: 10.1111/1365-2664.13805

Bahamonde, N., Carvacho, A., Jara, C., López, M., Ponce, F., Retamal, M. \& Rudolph, E. (1998). Categorías de Conservación de Decápodos Nativos de Aguas Continentales de Chile. Boletin Museo Nacional de Historia Natural, 47, 91-100. https://publicaciones.mnhn.gob.cl/668/ articles-65025 archivo_01.pdf

Bond-Buckup, G. \& Buckup, L. (1994). A família Aeglidae (Crustacea, Decapoda, Anomura). 
Arquivos de Zoologia, 32(4), 159-346. DOI: 10.11606/issn.2176-7793.v32i4p159-346

Bond-Buckup, G., Jara, C., Pérez-Losada, M., Buckup, L. \& Crandall, K. A. (2008). Global diversity of crabs (Aeglidae: Anomura: Decapoda) in freshwater. Hydrobiologia, 595(1), 267-273. DOI: 10.1007/s10750-007-9022-4

Bueno, S. L., Shimizu, R. M. \& Moraes, J. C. (2016). A remarkable anomuran: the taxon $\mathrm{Ae}$ gla Leach, 1820. Taxonomic remarks, distribution, biology, diversity and conservation. In: T. Kawai \& N. cumberlidge (eds.). A Global Overview of the Conservation of Freshwater Decapod Crustaceans. (pp. 23-64). Springer, London. UK.

Burns, J. W. (1972). The Distribution and Life History of South American Freshwater Crabs (Aegla) and Their Role in Trout Streams and Lakes. Transactions of the American Fisheries Society, 101(4), 595-607. DOI: 10.1577/1548-8659(1972)101<595:TDAL$\mathrm{HO}>2.0 . \mathrm{CO} ; 2$

Clarke, K. R. \& Gorley, R. N. (2006). PRIMER v6: User Manual/Tutorial. PRIMER-E Ltd: Plymouth.

CONAF-Corporación Nacional Forestal. (1999). Plan de manejo del Parque Nacional Huerquehue. Documento de Trabajo $N^{\circ} 318$. Ministerio de agricultura. Santiago de Chile, Chile. Cornejo, A., López-López, E., Sedeño-Diaz, J., Ruiz-Picos, R., Macchi, P., Kohlmann, B., .... Tunon, A. (2019). Protocolo de biomonitoreo para la vigilancia de la calidad del agua en afluentes superficiales de Panamá. Instituto Conmemorativo Gorgas de Estudios de la Salud. Panamá.

Correa-Araneda, F., Núñez, D., Díaz, M. E., Gómez-Capponi, F., Figueroa, R., Acuña, J., .... Esse, C. (2021). Comparison of sampling methods for benthic macroinvertebrates in forested wetlands. Ecological indicators, 125, 107551. DOI: 10.1016/j.ecolind.2021.107551

Dalosto, M. \& Santos, S. (2011). Differences in oxygen consumption and diel activity as adaptations related to microhabitat in Neotropical freshwater decapods (Crustacea). Comparative Biochemistry and Physiology Part A: Molecular \& Integrative Physiology, 160(4), 461-466. DOI: 10.1016/j.cbpa.2011.07.026
De los Ríos-Escalante, P. (2017). Non randomness in spatial distribution in two inland water species malacostracans. Journal of King Saud University - Science, 29(2), 260-262. DOI: 10.1016/j.jksus.2016.12.002

De los Ríos-Escalante, P., Avendaño, J. F. \& Suazo, M. J. (2019). Spatial distribution of Aegla rostrata Jara, 1977 (Decapoda, Anomura, Aeglidae) in the littoral of Pullinque Lake $\left(39^{\circ} \mathrm{S}\right.$, North Patagonia, Chile). Crustaceana, 92(4), 485-493. DOI: 10.1163/15685403-00003861

De los Ríos-Escalante, P., Meruane, J., Morales, M. C., Rudolph, E., Fuentealba, C. \& Boxshall, G. (2013). Zoogeography of Chilean inland water crustaceans. Latin American journal of aquatic research, 41(5), 846-853. DOI: 10.3856/vol41-issue5-fulltext-5

Di Castri, F. \& Hajek, E. (1976). Bioclimatología de Chile. Ediciones Universidad Católica de Chile. Santiago de Chile. Chile.

Domínguez, E. \& Fernández, H. (2001). Guía para la determinación de los artrópodos bentónicos Sudamericanos. Universidad Nacional de Tucumán, Facultad de Ciencias Naturales, Instituto Miguel Lillo. Tucumán. Argentina.

Domínguez, E. \& Fernández, H. (2009). Macroinvertebrados Bentónicos Sudamericanos. Sistemática y biología. Fundación Miguel Lillo. Tucumán. Argentina.

Feldmann, R. M. (1986). Paleobiogeography of two decapod crustacean taxa in Southern Hemisphere: global conclusions with sparse data. In: R. H. Gore \& K. L. Heck (eds.). Crustacean Biogeography. (pp. 5-19). CRC Press, Rotterdam. NLD.

Feldmann, R. M., Vega, F. J., Applegate, S. P. \& Bishop, G. A. (1998). Early Cretaceous arthropods from the Tlayúa formation at Tepexi de Rodríguez, Puebla, México. Journal of Paleontology, 72(1), 79-90. DOI: 10.1017/ S0022336000024033

Figueroa, J. (1983). Antecedentes para el manejo $y$ desarrollo del Parque Nacional Huerquehue IX Región. (Undergraduate. Tesis. Universidad de Chile, Chile). Descargada de: https://bibliotecadigital.infor.cl/handle/20.500.12220/3112

Figueroa, R., Palma, R., Ruiz, V. \& Niell, X. (2007). Análisis comparativo de índices bióticos utilizados en la evaluación de la calidad de 
las aguas en un río mediterráneo de Chile: río Chillán, VIII Región. Revista Chilena de Historia Natural, 80(2), 225-242. DOI: 10.4067/ S0716-078X2007000200008

Flint, O. (1983). Studies of neotropical caddisflies. New species from austral South America. (Trichoptera). Smithsonian Contribution to Zoologie, 337, 1-4. DOI: 10.5479/ si.00810282.377

Gómez, N., Donato, J. C., Giorgi, A., Guasch, H., Mateo, P. \& Sabatec, S. (2009). La biota de los ríos: los microorganismos autótrofos. In: A. Elosegui \& S. Sabater (Eds.). Conceptos y técnicas en ecología fluvial. (pp. 219-242.) BBVA, España.

Ilustre Municipalidad de Cañete. (2015). Plan de desarrollo comunal 2015-2020. Cañete. Chile.

INIA-Instituto de Investigaciones Agropecuarias. (2020). Red agrometeorológica del Instituto de Investigaciones Agropecuarias (INIA). Santiago de Chile. Chile.

IREN-Instituto Nacional de Investigaciones de Recursos Naturales. (1970). Estudio integrado de los recursos naturales: Provincia de Cautín. Informe $N^{\circ} 29$. Santiago de Chile. Chile.

Jara, C. (1996). Taxonomía, sistemática y zoogeografia de las especies chilenas del género Aegla Leach (Crustacea: Decapoda: Anomura: Aeglidae). (PhD. Tesis. Universidad de Concepción, Chile). Descargada de: http://repositorio.udec.cl

Jara, C. (2005). Crustáceos del género Aegla (Decapoda: Anomura) en la Cordillera de la Costa: su importancia para la conservación de la biodiversidad de aguas continentales en Chile. In: C. Smith-Ramírez, J. Armesto \& C. Valdovinos (eds.). Historia, biodiversidad y ecología de los bosques costeros de Chile. (pp. 307-323). Editorial Universitaria, Santiago de Chile. Chile.

Jara, C. (2013). A checklist of the Chilean species of the genus Aegla (Decapoda, Anomura, Aeglidae). Crustaceana, 86(12), 1433-1440. DOI: $10.1163 / 15685403-00003258$

Krammer, K. \& Lange-Bertalot, H. (1991). Bacillariophyceae 4. Teil: Achnanthaceae, kritische Ergänzungen zu Navicula (Lineolatae) und Gomphonema Gesamtliteratur verzeichnis. Gustav Fischer. Jena. Germany.

Krebs, C. J. (1988). Ecological Methodology.
Harper \& Collins Publishers. NY. USA.

López-Rojo, N., Pozo, J., Pérez, J., Basaguren, A., Martínez, A., Tonin, A. M., .... Boyero, L. (2019). Plant diversity loss affects stream ecosystem multifunctionality. Ecology, 100(12), e02847. DOI: 10.1002/ecy.2847

Luebert, F. \& Pliscoff, P. (2006). Sinopsis bioclimática y vegetacional de Chile. Editorial Universitaria. Santiago de Chile. Chile.

Mendiburu, F. (2020). Agricolae: Statistical Procedures for Agricultural Research. R Package Version 1.3-3. Available online: https:// CRAN.R-project.org/package $=$ agricolae

MMA-Ministerio del Medio Ambiente de Chile. (2013). Ficha de Antecedentes de Especie Aegla concepcionensis Schmitt, 1942. Santiago de Chile. Chile.

MMA-Ministerio del Medio Ambiente de Chile. (2014). Propuesta definitiva de clasificación de especies según su estado de conservación. Santiago de Chile. Chile.

Oyanadel, A. \& Valdovinos, C. (2004). Requerimientos de hábitat del cangrejo dulceacuícola $\mathrm{Ae}$ gla concepcionensis Schmitt, 1942. Una especie chilena en peligro de extinción. In: E. Wolf (ed.). Actas del XIII Taller Nacional de Limnología y ler Congreso de la Sociedad Chilena de Limnología. (pp. 42-43). Valdivia. Chile.

Palma, A., Figueroa, R., Ruiz, V. H., Araya, E. \& Berrios, P. (2002). Composición de la dieta de Oncorhynchus mykiss (Walbaum 1792) (Pisces: Salmonidae) en un sistema fluvial de baja intervención antrópica: Estero Nonguen, VIII región, Chile. Gayana, 66(2), 129-139. DOI: $10.4067 /$ S0717-65382002000200007

Parra, O. \& Bicudo, C. M. (1996). Algas de Aguas Continentales: Introducción a la Biología y Sistemática. Ediciones Universidad de Concepción. Concepción. Chile.

Parra, O., González, M., Dellarossa, V., Rivera, P. \& Orellana, M. (1982). Manual Taxonómico del Fitoplancton de Aguas Continentales, con especial referencia al Fitoplancton de Chile. Ediciones Universidad de Concepción. Concepción. Chile.

Peña, L. (1996). Introducción al Estudio de los Insectos de Chile (4ta. Edición). Editorial Universitaria. Santiago de Chile. Chile.

Pérez-Losada, M., Bond-Buckup, G., Jara, C. \& 
Crandall, K. A. (2009). Conservation assessment of southern South American freshwater ecoregions on the basis of the distribution and genetic diversity of crabs from the genus $\mathrm{Ae}$ gla. Conservation Biology, 23(3), 692-702. DOI: 10.1111/j.1523-1739.2008.01161.x

Pérez-Losada, M., Bond-Buckup, G., Jara, C. \& Crandall, K. A. (2004). Molecular systematics and biogeography of the southern South American freshwater "crabs" Aegla (Decapoda: Anomura: Aeglidae) using multiple heuristic tree search approaches. Systematic Biology, 5 (53), 767-780. DOI: 10.1080/10635150490522331

Pérez-Losada, M., Bond-Buckup, G., Jara, C. \& Crandall, K. A. (2002). Conservation phylogenetics of Chilean freshwater crabs Aegla (Anomura, Aeglidae): assigning priorities for aquatic habitat protection. Biological Conservation, 105(3), 345-353. DOI: 10.1016/ S0006-3207(01)00218-X

PRC-Plan Regulador Comunal de Pucón. (2019). Bases económicas, Informe 2: Modificación del PRC Adecuación y Aceptación, Etapa II: Ajuste Diagnóstico Comunal. Pucón. Chile.

Rallo, A. \& García-Arberas, L. (2002). Differences in abiotic water conditions between fluvial reaches and crayfish fauna in some northern rivers of the Iberian Peninsula. Aquatic Living Resources, 15, 119-128. DOI: 10.1016/S09907440(02)01156-7

Rallo, A., García-Arberas, L. \& Antón, A. (2004). Cambios en las condiciones físico-químicas y faunísticas de un sistema fluvial (río Oma, Bizkaia), y desaparición de una población de cangrejo autóctono (Austropotamobius pallipes): ¿Causa y/o efecto? Limnetica, 23(3-4), 49-60. DOI: 10.23818/limn.23.20

Rivera, P. (1983). A Guide for References and Distribution for the Class Bacillariophyceae in Chile between $18^{\circ} 28^{\prime} \mathrm{S}$ and $58^{\circ} \mathrm{S}$. Bibliotheca Diatomologica. Stuttgart. Germany.

Rodríguez-Capítulo, A., Muñoz, I., Bonada, N., Gaudes, A. \& Tomanova, S. (2009). La biota de los ríos: Los invertebrados. In: A. Elosegui \& S. Sabater (Eds.). Conceptos y técnicas en ecología fluvial. (pp. 253-270). BBVA. España.

Roldán, G. (1996). Guía para el estudio de los macroinvertebrados acuáticos del departa- mento de Antioquia. Universidad de Antioquia. Medellín. Colombia.

Round, F. E. \& Bukhtiyarova, L. (1996). Four new genera based on Achnanthes (Achnanthidium) together with a re-definition of Achnanthidium. Diatom Research, 11(2), 345-361. DOI: 10.1080/0269249X.1996.9705389

Santos, S., Bond-Buckup, G., Gonçalves, A. S., Bartholomei-Santos, M. L., Buckup, L. \& Jara, C. (2017). Diversity and conservation status of Aegla spp. (Anomura, Aeglidae): an update. Nauplius, 25, e2017011. DOI: 10.1590/2358$2936 \mathrm{e} 2017011$

Santos, S. \& De Siqueira Bueno, S. L. (2019). Aeglidae: Life history and conservation status of unique freshwater anomuran decapods. CRC PRESS. Boca Raton. USA.

Schaefer, H. C., Jetz, W. \& Böhning-Gaese, K. (2008). Impact of climate change on migratory birds: community reassembly versus adaptation. GlobalEcologyand Biogeography, 17,3849. DOI: 10.1111/j.1466-8238.2007.00341.x

Schmitt, W. L. (1940). Two new species of $A e-$ gla from Chile. Revista Chilena de Historia Natural, 40, 25-31. http://rchn.biologiachile. cl/pdfs/1940/1/Schmitt_1940.pdf

Schmitt, W. L. (1942). The species of Aegla, endemic South American fresh-water crustaceans. Proceedings of the United Estates $\mathrm{Na}$ tional Museum, 91, 432-520. DOI: 10.5479/ si.00963801.91-3132.431

Simonsen, R. (1987). Atlas and Catalogue of the Diatom Types of Friedrich Hustedt. J. Cramer. Berlin \& Stuttgart. Germany.

Smith-Ramírez, C., Armesto, J. \& Valdovinos, C. (2005). Historia, Biodiversidad y Ecología de los Bosques Costeros de Chile. Editorial Universitaria. Santiago de Chile. Chile.

Stefer, S., Moernaut, J., Melnick, D., Echtler, H. P., Arz, H., Lamy, F., .... Haug, G. H. (2010). Forearc uplift rates deduced from sediment cores of two coastal lakes in south-central Chile. Tectonophysics, 495, 129-143. DOI: 10.1016/j.tecto.2009.05.006

Thorne, R. \& Williams, R. (2003). The response of benthic macroinvertebrate to pollution in developing countries: A multimetric system of bioasssessment. Freshwater Biology, 37(3), 671-686. DOI: 10.1046/j.1365- 
2427.1997.00181.x

Tumini, G., Giri, F., Williner, V., Collins, P. A. \& Morrone, J. J. (2018). Distributional patterns of endemic southern South American freshwater aeglids (Crustacea: Decapoda: Anomura: Aeglidae). Zoologischer Anzeiger, 277, 55-64. DOI: 10.1016/j.jcz.2018.06.004

Valdovinos, C. (2019). El Cangrejo Tigre (Aegla concepcionensis). Laboratorio de Biodiversi- dad y Conservación de Recursos Acuáticos, Centro de Ciencias Ambientales EULA-Chile. Concepción. Chile.

Vidal, O. (2005). Flora exótica adyacente a senderos remotos en el Parque Nacional Torres del Paine (Magallanes - Chile). (Undergraduate tesis. Universidad Austral de Chile, Chile). Descargada de: http://cybertesis.uach.cl/tesis/ uach/2005/fcv649f/doc/fcv649f.pdf 